$$
\begin{aligned}
& \text { 201Tl-99 mTc サブトラクションシンチグラムの pit fall } \\
& \text { 一前縦隔胸腺腫と副甲状腺腫を合併した一例一 } \\
& \text { 1)福島県立医科大学内科学第三講座, 2)原町市立病院循環器内科, } \\
& \text { 3)福島県立医科大学外科学第二講座, 4)小高町立病院内科 } \\
& \text { 緑川早 苗1), 加藤健 }{ }^{1)} \text {, 新 村進1) } \\
& \text { 重 富 秀 一1), 鈴木史 雄2), 佐久間浩3) } \\
& \text { 鬼 満 圭 一3), 鈴木真 一3), 水野 兼 志4) }
\end{aligned}
$$

\title{
A Case of Primary Hyperparathyroidism Complicated by Anterior Mediastinal Tumor, Tl-Chloride Accumulative Thymoma
}

\author{
Sanae MIDORIKAWA ${ }^{1)}$, Ken $\mathrm{KATOH}^{1)}$, Susumu NIIMURA ${ }^{1)}$, \\ Shuichi SHIGETOMI ${ }^{1)}$, Fumio SUZUKI ${ }^{2)}$, Hiroshi SAKUMA ${ }^{3)}$, \\ Keiichi KIMAN ${ }^{3)}$, Shinichi SUZUKI ${ }^{3)}$ and Kenji MIZUNO ${ }^{4}$ \\ ${ }^{1)}$ The Third Department of Internal Medicine, Fukushima Medical College \\ ${ }^{2}$ Department of Cardiology, Haramachi Municipal Hospital \\ 3)The Second Department of Surgery, Fukushima Medical College \\ ${ }^{4)}$ Department of Internal Medicine, Odaka Municipal Hospital
}

The ectopic parathyroid tumor, especially the mediastinal parathyroid adenoma, is not so rare, therefore the diagnosis of preoperative localization is necessary to obtain good results of surgical removal.

We report a 65 -year-old female of primary hyperparathyroidism complicated by an anterior mediastinal tumor. She was admitted for further evaluation of hypercalcemia. Her serum calcium and parathyroid hormone, intact-PTH, levels were slightly elevated with increased urinary calcium excretion. A chest X-ray indicated an abnormal tumorous shadow in the mediastinum, below the aortic arch. Computed tomography of the upper mediastinum showed a round well-enhanced mass in the rear, left of the sternum. ${ }^{201} \mathrm{Tl}-{ }^{99} \mathrm{~m} \mathrm{Tc}$ subtraction scintigraphy revealed a definite accumulation of the isotope in the mediastinal tumor with no clear accumulation in the neck. These findings indicated a diagnosis of primary hyperparathyroidism due to an ectopic parathyroid tumor, although the aspiration sample obtained by the transthoratic needle suggested a thymoma. The anterior mediastinal tumor and left inferior parathyroid gland were removed and a histological examination indicated a diagnosis of benign thymoma and parathyroid adenoma, respectively. Postoperatively, her serum calcium and intact-PTH were normalized.

${ }^{201} \mathrm{Tl}-99 \mathrm{~m} \mathrm{Tc}$ subtraction scintigraphy is useful to detect the preoperative localization because it is not invasive and a positive image could be obtained whether parathyroid tumors exist in an abnormal site not just behind the thyroid. But as in this case, if the hyperparathyroidism would be come complicated by the tumor, wherein Tl-chloride accumulates, this scintigraphy is not useful for the preoperative localization of the hyperparathyroidism. In this case, we would need to focus a lot of attention on the detection for preoperative 
localization by ${ }^{201} \mathrm{Tl}-99 \mathrm{~m} \mathrm{Tc}$ subtraction scintigraphy to prevent re-operation due to postoperative continuous hypercalcemia.

Keywords: primary hyperparathyroidism, ectopic parathyroid tumor, thymoma, ${ }^{201} \mathrm{Tl}-99 \mathrm{~m}$ Tc subtraction scintigraphy, preoperative localization

\section{緒 言}

原発性副甲状腺機能立進症は近年血清カルシウム值がスクリーニングされ, 無症状のものも含めて 多数発見されるようになった。また高精度の副甲状腺ホルモン (intact-PTH) の測定が可能となり， その存在診断は比較的容易であるとされている。しかし原発性副甲状腺機能九進症では, 必ずしも常 に血清カルシウム值や副甲状腺ホルモンが高値を呈するとは限らず1)，明らかな骨症状や腎症状がな い場合などは診断が困難な事も少なくない。

さらに本疾患の部位診断については, 非侵襲的な検査である超音波検査やシンチグラムの発達によ り，術前部位診断が可能となっているが，部位診断のための検査を施行する必要があるかどらかにつ いては議論が多い。

今回我々は， ${ }^{201} \mathrm{Tl}$-chloride が集積する前縦隔腫瘍（胸腺腫）を合併し，頸部に存在した副甲状腺 腫の術前部位診断が困難であった症例を経験したので報告する。

\section{症例}

患 者: 65 歳, 女性。

主 訴: 全身倦总感。

家族歴 : 父 胃癌, 母 胆石症。

既往歴 : 24 歳, 結核性胸膜炎。腎結核にて右腎摘出術。

32 歳, 右卵巣のう腫。

58 歳, 胆石症。

現病歴：64 歳，特に自覚症状はなかったが健診を受け，腹部超音波検査にて左腎結石を疑われたが， 内視鏡検査では結石は発見されなかった。

65 歳, 全身倦怠感が出現したため, 原町市立病院を受診し, 血液検査にて血清カルシウム $14.1 \mathrm{mg} / \mathrm{dl}$, アルブミンによる補正血清カルシウム $13.7 \mathrm{mg} / \mathrm{dl}$, 血清リン $5.5 \mathrm{mg} / \mathrm{dl}$ と著明な高カ ルシウム血症を認めた。intact-PTH は $59 \mathrm{pg} / \mathrm{ml}$ と高カルシウム血症にもかかわらず軽度高值であ ったため, 原発性副甲状腺機能六進症を疑われ，精査加療を目的に福島医大第三内科を紹介され入院 した。

入院時現症：身長 $146.5 \mathrm{~cm}$, 体重 $47.5 \mathrm{~kg}$ 。血圧は $108 / 60 \mathrm{mmHg}$ であり，脈拍は $64 /$ 分，整であっ た。頸部では甲状腺腫および腫瘤を触知しなかった。胸部では両側中下肺野に fine crackle を聴取し た。前脛骨部には浮腫を認めず，膝蓋腱反射扣よびアキレス腱反射に異常を認めなかった。

入院時一般検査成績 (Table 1):末梢血液検査で軽度の貧血を認め, 血液像ではリンパ球が軽度増加し ていた。生化学的検査では肝機能に異常を認めなかったが, ALP の isozyme は osteoblast 由来のも 
Table 1 Laboratory findings on admission

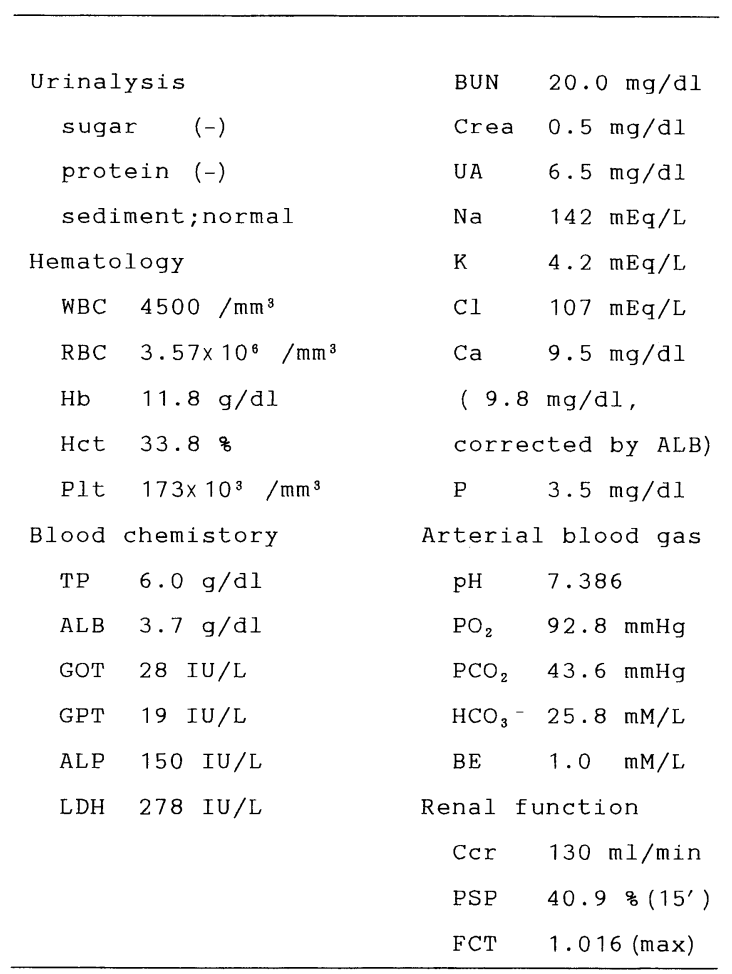

のが増加していた。血清電解質では血清カルシウムが $9.5 \mathrm{mg} / \mathrm{dl}$, 補正血清カルシウムが $9.8 \mathrm{mg} / \mathrm{dl}$ とともに正常上限であり, 血清リンは正常であった。またイオン化カルシウムは, $1.315 \mathrm{mM} / \mathrm{L}$ (正 常 $1.0 \sim 1.2)$ と明らかに高值であった。さらに尿中カルシウム排泄量は常に高值であり，尿中リン排 泄量は正常であった。

動脈血酸塩基平衡では代謝性アシドーシスは認めなかった。

腎機能では濃縮力が軽度低下していたが，クレアチニンクリアランスは正常であった。

内分泌学的検查成績 (Table 2):intact-PTH は $48 \mathrm{pg} / \mathrm{ml}$ と正常上限であった。カルシトニンおよび PTH-rP は正常であった。尿中カルシウム排泄は増加し， $\mathrm{FE}_{\mathrm{Ca}}$ は上昇していたが，\%TRP は正常で あった。

甲状腺機能，下垂体ホルモン，尿中カテコールアミン排泄量に異常を認めなかった。

画像診断：手指骨拈よび頭蓋骨単純写真では異常を認めなかった。

頸部超音波検査および頸部 CT では甲状腺に異常を認めず, 副甲状腺腫と考兄られる腫瘤も発見 されなかった。

胸部単純 X 線写真 (Fig. 1) で前緃隔に腫瘤陰影を認め, 胸部 CT (Fig. 2) では胸骨後方やや左側に 直径 $3 \mathrm{~cm}$, 辺縁平滑で均一に造影される腫瘍陰影を認めた。

${ }^{201} \mathrm{Tl}-99 \mathrm{~m} \mathrm{Tc}$ サブトラクションシンチグラム (Fig. 3) では縱隔腫瘍の部位に一致して放射活性の集積 第 72 巻 第 4 号 
Table 2 Endocrinological findings

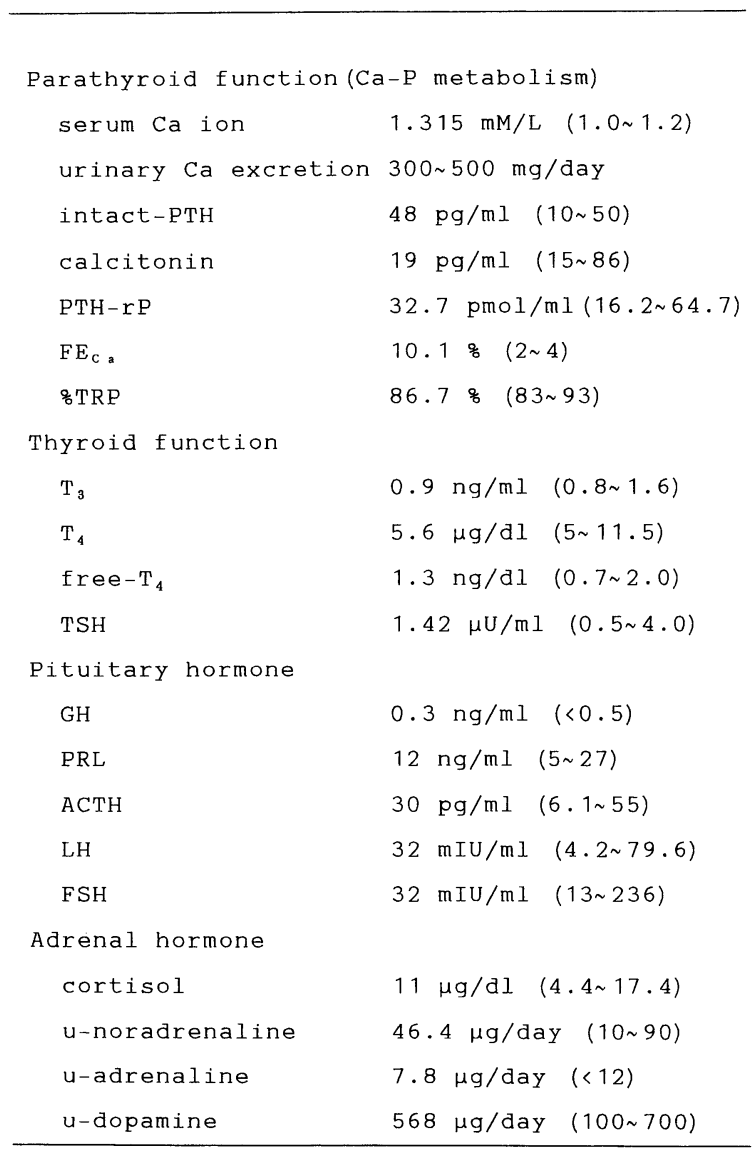

を認めたが，頸部には集積を認めなかった。Ga シンチグラムでは異常集積は認めなかった。

入院後経過：尿路結石や線維性骨炎は無く, また検査成績でも代謝性アシドーシスや低リン血症など 原発性副甲状腺機能充進症の典型例で認められる所見は無かったが, 血清イオン化カルンウムは常に 高值で, 尿中カルシウム排泄量は増加し, 高カルシウム血症にもかかわらず intact-PTH が抑制不十 分であったことより，原発性副甲状腺機能立進症と診断した。画像診断より前縦隔腫瘍の存在は明ら かで, かつ, ${ }^{201} \mathrm{Tl}-99 \mathrm{~m} \mathrm{Tc}$ サブトラクションシンチグラムが陽性であり, 異所性副甲状腺腫が疑われ たが, 縱隔腫疸の大きさに比し血清カルシウム值怙よび副甲状腺ホルモンの上昇が軽度であることか ら，縱隔腫瘍の質的診断を目的に経皮的腫瘍針吸引細胞診，選択的静脈サンプリングおよび血管造影 を施行した。細胞診上胸腺腫が疑われ，他の検査では質的診断に寄与し得る検查結果は得られなかっ た。したがって病的副甲状腺の部位診断は明確ではなく, 胸腺腫と合併して通常部位に病的副甲状腺 が存在している可能性も考兄られた。以上より平成 6 年 12 月 13 日, 本学第二外科にて手術を施行し た。 


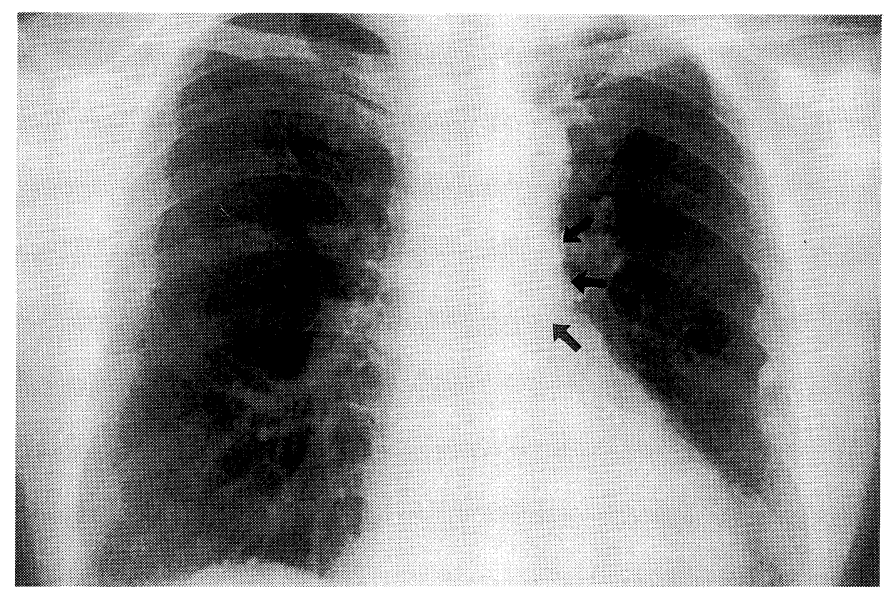

Fig. 1 Chest X-ray film on admission. An abnormal tumorous shadow is demonstrated in the mediastinum below the aortic arch.

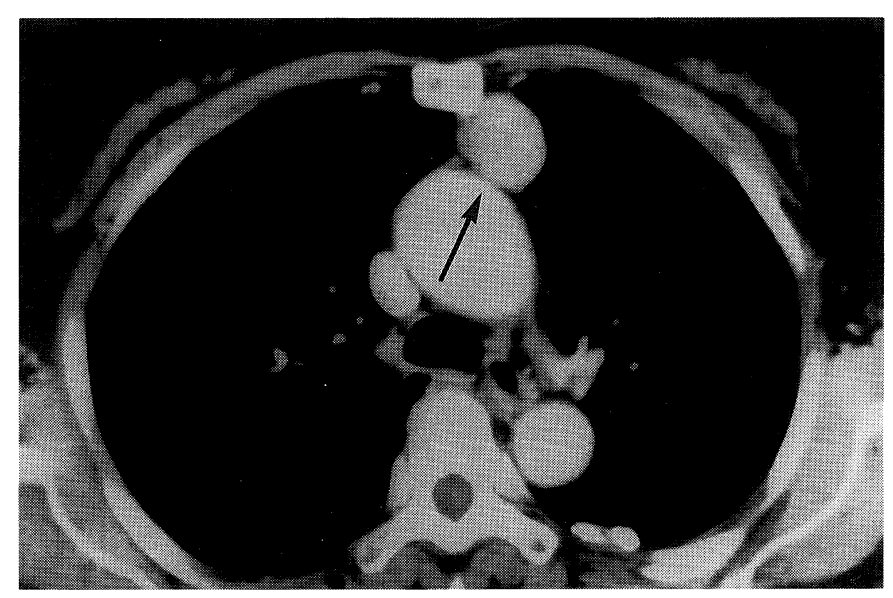

Fig. 2 Computed tomography shows a round well-enhanced mass in the rear, left of the sternum.

手術所見および術後経過 : 胸骨縦切開下縱隔腫瘍摘出術および両側下副甲状腺切除術を施行した。前 縱隔腫瘍は大きさが $43 \times 35 \mathrm{~mm}$, 重量 $8.7 \mathrm{~g}$, 被膜に覆われ, いくつかの結節に分葉していた。内 部は充実性であり, のう胞, 出血扤よび壊死巣は認めなかった。組織学的 (Fig. 4) には異型のない成 熟小型リンパ球より構成されており，上皮成分にも異型を認めず，良性胸腺腫と診断した。

副甲状腺は右下部が大ささ約 $5 \times 2.5 \mathrm{~mm}$, 重量 $50 \mathrm{mg}$, 左下部が大ささ約 $6 \times 3.5 \mathrm{~mm}$, 重量 $65 \mathrm{mg}$ であった。両側上副甲状腺は発見できなかった。組織学的には左下部のものに, 結節状の主細 胞の増殖を認め, 副甲状腺腫と診断した (Fig. 5)。核分裂像や異型細胞は認めなかった。右下部は萎 縮した副甲状腺組織であった (Fig. 6)。術後の血清総カルシウムは $8.5 \mathrm{mg} / \mathrm{dl}$, 補正血清カルシウム 


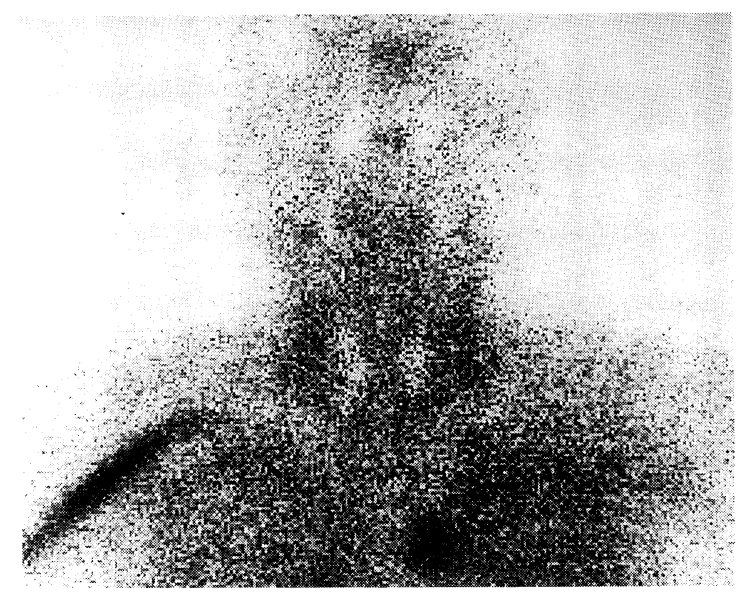

Fig. $3{ }^{201} \mathrm{Tl}-99 \mathrm{~m} \mathrm{Tc}$ subtraction scintigraphy reveals a definite accumulation of the isotope in the mediastinum with no clear accumulation in the neck.

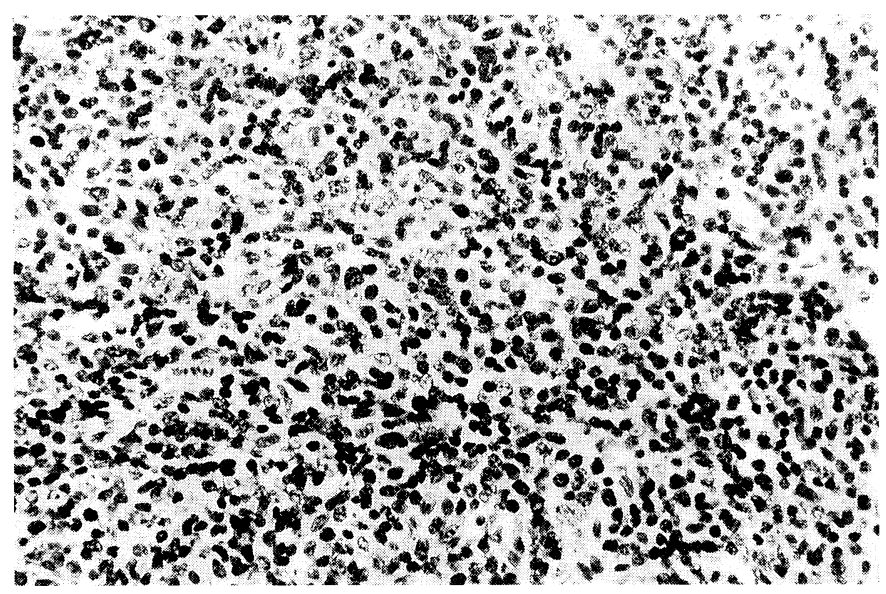

Fig. 4 Histological findings of the anterior mediastinal tumor. The tumor is composed of a lot of small lymphocytes and epithelial cells and diagnosed benign thymoma (HE stain, $\times 400$ ).

は $8.9 \mathrm{mg} / \mathrm{dl}$ と術前より低下した。さらにイオン化カルシウムは $1.13 \mathrm{mM} / \mathrm{L}$ と正常化し, また intact-PTH は $23 \mathrm{pg} / \mathrm{ml}$ と低下した。

考察

血清イオン化カルシウムの測定ならびに活性を有する副甲状腺ホルモン (intact-PTH) の測定法が 開発されたことによって, 典型的な症状を呈さない, 化学型に分類される原発性副甲状腺機能九進症 


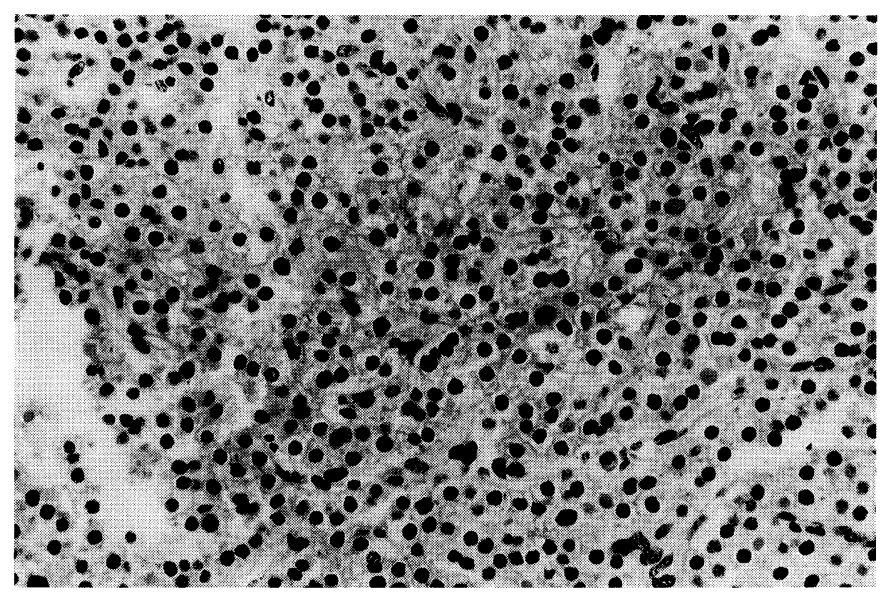

Fig. 5 Microscopic findings of the left inferior parathyroid gland, demonstrating proliferation of the eosinophilic chief cells, diagnosed parathyroid adenoma (HE stain, $\times 400)$.

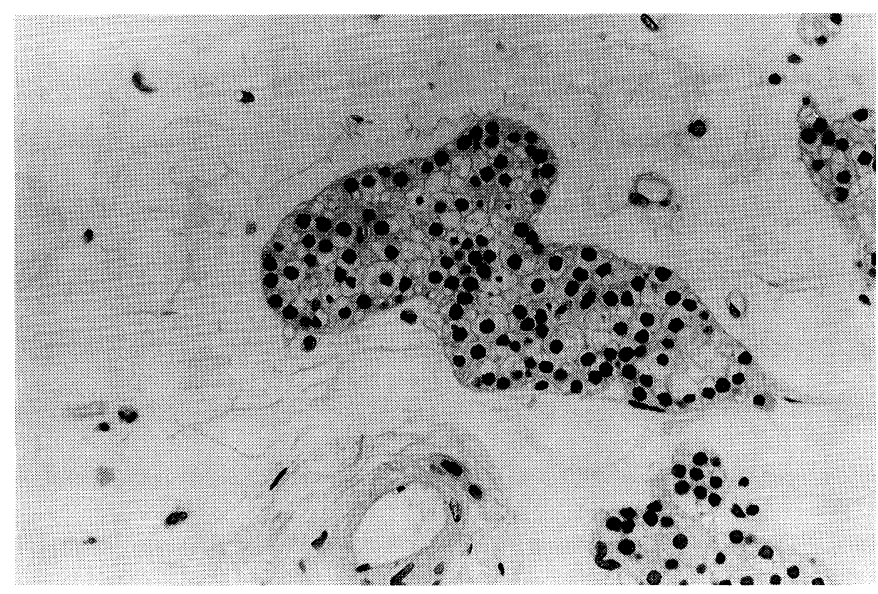

Fig. 6 Microscopic findings of the right inferior parathyroid gland, showing the atrophic parathyroid tissue (HE stain, $\times 400$ ).

が数多く発見され, 重篤な合併症が出現する前に適切な対処が可能となっている。副甲状腺腫の部位 診断は，非侵襲的な超音波検査にて術前部位診断がなされることが多いが，本症例では腫瘤が非常に 小さく，詳細な検索を反復して行っても部位診断が不可能であった。

また臨床上，甲状腺裏面以外の部位に存在する，いわゆる異所性副甲状腺腫は 15２2\%と比較的 高頻度で存在する233)。異所性副甲状腺腫は特に縱隔内に多く存在するが， ${ }^{201} \mathrm{Tl}$ と ${ }^{99 \mathrm{~m}} \mathrm{Tc}$ を用いたサ ブトラクションシンチグラムはその撮影部位を胸部をで広げることで，異所性副甲状腺腫にも威力を 発揮し, 超音波検査など部位診断のために施行する他の検査に比べ高い診断率が得られると報告さ 
れ4)5)，最小の検出可能であった腫瘍重量は $0.02 \mathrm{~g}$ との報告もある6。

本症例は原発性副甲状腺機能充進症の精査中に前縱隔腫瘍が発見され, この腫瘍に ${ }^{201} \mathrm{Tl}$-chloride が集積したことから, 異所性副甲状腺腫が疑われたが, 吸引細胞診により胸腺腫と診断したため, 他 の部位に病的副甲状腺が存在することが予想され, 甲状腺左下部に存在した腺腫を手術により摘出し 得た。本症例で副甲状腺腫に ${ }^{201}$ Tl-chloride が集積しなかった理由として，宮川らフは，二つ以上の 副甲状腺腫がある場合には大きい腫瘤のみ描出され, 小さい腫瘤は描出されないことがあると報告し ており，本症例の場合も副甲状腺腫に比し胸腺腫が著しく大であったことより， ${ }^{201}$ Tl-chloride が胸 腺腫にの久集積し, 副甲状腺腫に集積が認められなかった可能性が考えられる。さらに腫瘍組織に ${ }^{201}$ Tl-chloride が集積する機序としては, 組織の血流量の増加を反映するとするもの ${ }^{8)} \mathrm{Na}^{+}-\mathrm{K}^{+} \mathrm{AT}$ Pase の関与9110)，また組織内のミトコンドリアの多い好酸性細胞に集積する11) などさまざまな報告が なされて抢り, 本例のように腫瘍の大きさばかりでなく, 胸腺腫と副甲状腺腫といら異なった組織由 来の腫瘍では, ${ }^{201} \mathrm{Tl}$-chloride の集積性に差があることは十分予想される。以上より， ${ }^{201} \mathrm{Tl}-99 \mathrm{~m} \mathrm{Tc}+$ ブトラクションシンチグラムは原発性副甲状腺機能六進症の部位診断には有用性が高いと思われる が， ${ }^{201}$ Tl-chloride 集積性の腫瘍を合併している場合には，その解釈には慎重を要すると考劣られる。

本症例のよらな原発性副甲状腺機能京進症と同時に異所性副甲状腺腫の好発部位である縱隔に他の 腫瘍を合併している例はまれである。本症例で原発性副甲状腺腫と胸腺腫の合併が予想された事から， MEN-type I の合併が疑われ，下垂体及び膵の精查も行ったが異常は発見されず，MEN-type I は除 外し得ると考兄られる。Rizzoli，R. ら ${ }^{12)}$ は胸腺腫から副甲状腺ホルモンが分泌され副甲状腺機能六 進症を呈した症例を報告しているが，副甲状腺腫は発見されていない。また，胸腺過形成と原発性副 甲状腺機能充進症（副甲状腺過形成）の合併例が報告されている13) が，この症例では胸部 CT にて 胸腺の腫大を認め, 異所性副甲状腺腫と診断され切除術が施行されたが, 高カルシウム血症が改善せ ず再手術が施行された。よって原発性副甲状腺機能六進症の患者で縱隔などの異所性副甲状腺腫の好 発部位に腫瘍を合併している場合には, シンチグラムで病的副甲状腺に ${ }^{201}$ Tl-chloride が集積しない 場合もあることを考虑に入れ，病的副甲状腺の部位診断や合併している腫瘍の質的診断のために，吸 引細胞診や選択的静脈サンプリング等をも併用し，総合的に術前の部位診断に努めるべきであり，こ れにより術後の持続性機能立進による再手術など患者の身体的，精神的負担を軽減させ得ると考兄ら れる。

\section{結語}

緹隔腫痬（胸腺腫）を合併し, 術前に副甲状腺腫の部位診断が困難であった原発性副甲状腺機能え 進症を経験した。近年, 本疾患の部位診断には ${ }^{201} \mathrm{Tl}-{ }^{99} \mathrm{~m} \mathrm{Tc}$ サブトラクションシンチグラムが注目さ れ，その診断率は高く異所性副甲状腺腫にも有効であるとされているが，本症例のように異所性副甲 状腺腫の好発部位に ${ }^{201}$ Tl-chloride の集積する腫瘍を合併した原発性副甲状腺機能六進症に抢いては, 病的副甲状腺に ${ }^{201} \mathrm{Tl}$-chloride が集積しないことがあり，本検査の解釈には十分注意を払うべきと考 えられる。 


\section{文献}

1) 小原孝男 : 原発性副甲状腺機能六進症の診断と治療. 日内分泌会誌. 1992; 68: 1167-1176

2) Wang, C.A.: The anatomic basis of parathyroid surgery. Ann. Surg. 1976; 271: 183-186

3) Clark, O.H.: Mediastinal parathyroid tumors. Arch. Surg. 1988; 123: $1096-1100$

4) Makiuchi, M., Miyakawa, M., Sugenoya, A., Senga, O., Kobayashi, S., Shirota, H., Nakanishi, F., Kasuga, T.: Diagnostic usefulness of ${ }^{201} \mathrm{Tl}$-chloride scintigraphy for preoperative localization of parathyroid tumors. Jan. J. Surg. 1981; 11: $162-166$

5) 福地 稔, 末廣美津子, 日下部きょ子, 牧 正子, 大塚信昭, 片桐 誠, 鳥塚莞爾: 副甲状腺疾患に打ける塩化タリ ウム $\left.{ }^{201} \mathrm{Tl}\right)$ 注射液の有用性. 核医学. 1993; 30: $1481-1490$

6) 鐘ケ江香久子, 伊藤和夫, 加藤千恵次, 永尾一彦, 中䭾邦博, 藤森研司, 古館正従 : ${ }^{201} \mathrm{Tl}-99 \mathrm{~m} \mathrm{Tc}$ サブトラクションシ ンチグラフィーによる原発性および二次性副甲状腺機能克進症の局在診断. 核医学. 1994; 31: $441-449$

7) 宮川 信, 千賀 脩, 春日好雄, 横沢 保, 菅谷 昭, 飯田 太: 原発性上皮小体機能充進症一部位診断一. 内分泌 外科. 1993; 1: $157-165$

8) 中西文子, 春日敏雄, 小林俊雄, 牧内正夫, 宮川 信 : 副甲状腺腫瘍局在診断に対する ${ }^{201} \mathrm{Tl}$-chloride シンチグラフィー の有用性. 核医学. 1981; 18: 309-314

9) Elligsen, J.D., Thompson, J.E., Frey, H.E., Kruuv, J.: Correlation of (Na-K)-ATPase activity with growth of normal and transformed cells. Exp. Cell. Res. 1974; 87: $233-240$

10) Brittes, J.S., Blank, M.: Thallium activation of $\left(\mathrm{Na}^{+}-\mathrm{K}^{+}\right)$activated ATPase of rabbit kidney. Biochem. Acta. 1968; 159: $160-166$

11) Sandrock, D., Merino, M.J., Norton, A.J., Neumann, R.D.: Ultrastructural histology correlates with results of Thallium201 / Technetium-99m parathyroid subtraction scintigraphy. J. Nucl. Med. 1993; 34: 24-29

12) Rizzoli, R., Pache, J.C., Didierjean, L., Burger, A., Bonjour, J.P.: A thymoma as a cause of true ectopic hyperparathyroidism. J. Clin. Endcrinol. Met. 1994; 79: $912-915$

13) 石井昌俊, 大石 明, 渡部玲子, 金子光太郎, 青崎 登, 影山隆久, 吉松 博, 梅沢明弘, 杉浦 仁, 浜口欣一: 胸 腺過形成に原発性副甲状腺機能六進症を合併した慢性腎不全の 1 例. 日本内科学会関東地方会抄録集. 3. 1991; 150

(受付日 : '95, 7, 28)

（採択日：'95, 11, 5) 